\title{
Making valuable health: pharmaceuticals, global capital and alternative political economies
}

\author{
Jean-Paul Gaudilliere ${ }^{1} \cdot$ Kaushik Sunder Rajan ${ }^{2}$
}

Accepted: 7 August 2021 / Published online: 4 September 2021

(C) The Author(s), under exclusive licence to Springer Nature Limited 2021

Historical and anthropological analyses of biomedicine have in recent years highlighted various global trajectories by which health has become capitalized. An empirical focus of these analyses has been the critical role that pharmaceuticals have acquired through the latter half of the twentieth century and into the twenty-first (Bächi 2009; Biehl 2009; Cooper and Waldby 2014; Dumit 2012; Gaudillière and Hess, 2013; Gaudillière and Thoms 2015; Greene 2007, 2014; Haller 2012; Hayden 2007; Peterson 2014; Petryna and Kleinman 2006; Petryna 2009; Sunder Rajan 2017). Healthcare has progressively come to be indexed by pharmaceutical consumption, a process that various scholars have described as 'pharmaceuticalization' (Abraham 2010; Bell and Figurt 2012; Biehl 2007). The papers in this collection consider the ways in which the capitalization of health operates globally, by means of pharmaceuticalization.

We understand capitalization, minimally, as the conversion of goods, people and actions into assets that can be profitably invested. We argue that capitalization abstracts health, rendering it less a state of embodied, subjective health and more a form of value that can be grown. This abstraction increasingly operates alongside a reduction of health and illness to something that can be addressed through access to and consumption of drugs, emptying the idea of healthcare of meanings that do not involve access to medication. Such consumption is itself enabled and constrained institutionally, for instance by professional norms, public policies and the differential constitution of markets. This co-production of pharmaceuticalization with the

Jean-Paul Gaudilliere

jean-paul.gaudilliere@cnrs.fr

Kaushik Sunder Rajan

ksunderr@uchicago.edu

1 CERMES-INSERM, Paris, France

2 The University of Chicago, Chicago, USA 
capitalization of health is mediated by globalized attempts at institutional homogenization. Thus, one sees discourses and strategies of 'harmonization'-for instance by defining priority diseases, establishing standard practices and enlarging the circulation of medical products and services-even as experimental and therapeutic markets are deeply striated and unequal in actuality (Adams 2016, Coderey and Pordié 2016, Gaudilliere et al 2020, 2021, Livingston 2012, Peterson 2014, Petryna and Kleinman 2006).

We take the reciprocal co-productions of capitalization, pharmaceuticalization and globalization as the point of departure for our analyses in this special issue. We argue that these have reconstituted our understandings of health, while contributing to the emergence of governance regimes and the realization of new forms of value. Thus, this collection of essays considers the capitalization of health as something more than a process of invention, production and commercialization of drugs, and more than just a change of actors and targets in international health initiatives. Rather, there are multiple entanglements of labor, circulation and governance that bring together drugs, pharmaceuticalized care and global health, in order to instantiate new political economies.

The papers trace these entanglements in order to consider the making of valuable health and its diverse political economies as historical and anthropological problems (Ong and Collier 2005). We purposefully develop a comparative and scalar perspective traversing categories of biomedicine and traditional medicine; metropolitan and 'global Southern' locales; corporate and public health contexts; nation-state and transnational regimes/institutions of governance. Our animating assumption is that value is a polyvalent concept. It speaks to market value (which entails use and exchange but, when legible to capital, becomes self-valorizing, entering the relentless generation of surplus), to practices of production, and to epistemic and normative choices. Similarly, the political economies that materialize are not singular, nor are they simply instituted 'from above', even as particular regimes of state or corporate governance might come to be hegemonic in particular places and times. They are constantly contested, not least because capitalized, pharmaceuticalized and globalized regimes of value cannot exist without institutions and processes of governance (Aglietta 1979). Such governance might enable capitalization as much as it might constrain it. It might incentivize certain forms or trajectories of capitalization rather than others. And so, even as capital appropriates health and expands its domains, it encounters political terrains that must be situationally negotiated.

\section{Making valuable health: a framework}

The papers in this special issue attend to moments at which value gets made in its multiple forms, through the consolidation, contestation or imagination of certain kinds of markets. It builds on four theoretical entry points:

First, we take seriously Marx's lessons on the logics of capital, as grounded constantly in the generation of surplus. Marx shows how value in capital is not a thing but a process, specifically one of self-valorization. Indeed, capitalist value presupposes self-valorization: value is value because it makes more value. This is 
fundamental to the dynamics of capital: one cannot have capital without self-valorizing value. Left to itself, this valorization cannot set itself limits; therefore, there is a constant tendency for capital to accumulate, and to appropriate domains that are outside itself.

Marx insisted that any proper understanding of capital has to begin with an analysis of the question of value. He says as much in The Grundrisse: "To develop the concept of capital it is necessary to begin not with labor but with value, and precisely, with exchange value in an already developed movement of circulation" (Marx 1993 [1857], p. 259). And for capital, value has no meaning unless it is surplus value. For money to be capital, it must have the potential for generating surplus as it circulates in processes of commodity exchange. In relation to the situation of European (especially English) industrial capitalism that Marx was writing about, this potential comes from what he called labor power-the potential for the worker to generate more labor than that compensated by wage. More generally, Marx provides a methodological insight into how capital generates value through an exploitation of bodily potential, even as the generation of value becomes an end in itself. Further, value is that which allows the commodity, which is always the product of specific and concrete human labor, to figure as abstract labor. At the core of Marx's critique of political economy is his insistence that value is an abstraction device.

Therefore, on the one hand, value is simply an attribute (something that a commodity has: its utility, its beauty, its ability to be worn or eaten; something that money has: its ability to circulate itself, to mediate and measure other kinds of circulations, to quantitatively express circulation itself). This attribute is realized through processes of exchange in capitalist markets. Yet to understand Marx's analysis of the dynamics of value, it is important to emphasize that value is something more or other than exchange. Indeed, Marx begins his analysis of capital in Volume 1 of Capital by discussing three types of value: use value, exchange value, and a third, which he refers to, simply, as "value" (Marx 1867 [1976]). This third category of value is distinct from the first two, which reflect the utility of a commodity and anthropological processes of circulation, respectively. This third category, which is the foundation of capital (and Capital), is defined by self-valorization. Purely within the calculus of self-valorization, questions of utility are rendered secondary by capital.

Yet second, capitalization only renders one dimension of value as it operates in the worlds of pharmacy and global health. This speaks to the situated perspective of 'capital' in biocapital. It does not completely capture the material, the epistemic and the normative facets of value (Sunder Rajan 2017, Introduction). These latter dimensions are always potentially appropriable by capital, but can also counter hegemonic logics of capital by providing alternative modalities of evaluation. As a consequence, the problem of medical utility does not disappear, and diverse drug economies emerge through these specific arrangements of production, circulation and consumption, speaking to the 'bio' in biocapital. One should therefore refuse the elision of questions of use that are at the heart of logics of capital accumulation even in its most abstracted embodiment, namely that of the financial and speculative economy. One sees this materialize in patterns of local non-industrial production, generic manufacturing, illegal circulation or mass-production of traditional herbal 
remedies. Taken together, these alternative materializations are not necessarily alternatives to capital. Nonetheless, they make explicit the different political pressure points in pharmaceutical value generation, having to do with epistemic choices, medical utility and commodity exchange.

Third, we recognize the inherent contradictions within health markets as they are constituted via sometimes competing biocapitalist and biopolitical rationalities. Even as health is capitalized, the health of a population must be maintained and sustained, both to ensure for the continuity of the social and political order of things (Foucault 2004a) and in order to ensure that this population remains useful. Hence the necessity of reproducing labor power, as classical political economy and Marx himself pointed out. As health has historically been perceived as an essential attribute of labor, it has become the focus of intense battles for public intervention and protection.

As a consequence, health expenditures and/or provision of care have been socialized through workers' cooperative schemes, taxation, employers-based insurance and state-based programs, albeit in particular locales and uneven ways. This socialization of health expenditures has provided for one of the strongest and largest components of 'welfare' regimes on the one hand (Esping Andersen 1990; Castel 2002) and for a seemingly irrepressible logic of generalized access to biomedical goods, eventually of contested therapeutic value, on the other (Dumit 2012; Kaufman 2015). Health markets thus negotiate in acute ways the tension between logics of biocapital (self-valorizing value through an appropriation of health and life to generate surplus) and biopolitical rationalities (care of the population through rationalities of governance and management). This essential tension is powerfully reflected in the recurrent discussions economists have had on the limits of individuals' payments, the role of public investments in health and of public goods in response to market failures (World Bank 1993; Chorev 2012).

How that tension takes particular forms and logics under contemporary forms of global capitalism is a critical question. For two decades, as a consequence of the debt crisis, structural adjustment policies implemented by the IMF and the World Bank, financing reforms of welfare systems, or the rise of venture capital in research, much emphasis has been placed on the logic of 'privatization' and the decreasing role of nation-states. Specific to the health sector is however the fact that this displaced boundary between 'public' and 'private' coexists with another trend, namely the rise of new forms of management associated with audit cultures and the optimization of public investments. As Foucault pointed out in his acute reading of neo-liberalism, for its promoters the issue was never to marginalize the state but to change its logic of action in favor of market construction (Foucault 2004b). The theory of human capital [Gary Becker] and its translations into policies promoting both public investments in - and valorization of - health or education stands at the crossroad of such neo-liberal government (Chorev 2012; Gaudillière 2014; Murphy 2017).

Fourth, we explore how this dialectic of capital and biopolitics produces alternative political economies of health in ways that are frictioned and fraught, both politically and economically. Valorization may be self-valorizing, but is not self-sustaining. In spite of the much discussed autonomy of finance, the making of value is predicated on the materialization and realization of anticipated value, and therefore 
on the government of goods and services, on the ability to complete the cycles of investments and sales, exchange and use. The materialization and realization of value depends upon rationalities and regimes of governance within which capitalization, pharmaceuticalization and globalization operate. Consequently, the generation of value is instantiated within particular historical and political trajectories that constitutes diverse and partly overlapping temporal and spatial regimes of accumulation (Boyer 2015).

Health valorization therefore:

(i) Speaks to the capitalization of health, via processes of both commodification and financialization, while revealing heterogeneous and sometimes competing product chains, enterprises, and systems of property;

(ii) Diversifies the processes and meanings of pharmaceuticalization (Biehl 2007) beyond the problems of access and processes of biomedicalization (Clarke et al. 2010), for instance by the incorporation of so-called 'traditional practices' into global therapeutic circuits;

(iii) Elaborates globalization across axes of scales of healthcare intervention (local to national to regional to global), and historical transitions from international/ ist imaginaries of health government of the 1970s animated by the sentiment of 'Third Worldism' and postcolonial international solidarity, to today's 'global health', grounded in promises of technocratic and speculative innovation, audit cultures and economized logics of public health intervention.

Elucidating alternative political economies is therefore a historically situated comparative project, one in which the parameters of comparison are not necessarily symmetrical or commensurable. Logics of capital and biopolitical rationalities are not simply metropolitan logics that 'touch down' in global peripheries; these logics and rationalities have multiple sites and scales of emergence and instantiation. The dialectic between capital and biopolitics has opened spaces for innovation and market construction outside Europe and North America. Generics, herbal preparations, informal products and copies, and 'Southern' pharmaceutical economies stand at odds with the hegemonic regime of post-World War II pharmacy, dominated by patents and their logic of monopolistic appropriation, and by molecular and chemical knowledge as the epistemic foundation of valuable therapeutic intervention. 'Southern' political economies of health materialize original and differentiated links between alternative modes of capitalization and alternative modes of care, even as they are constrained by hegemonic formations of capital and governance that are not always of their own making. Investigating these configurations is therefore an entry point into projects that both resonate with the post-war 'development' agendas and challenge them, providing for alternative forms of modernity (Chatterjee 1993). These deeply situated configurations must be thought in relation to value-logics of capital that are abstract, deterritorialized and constantly expanding into and appropriating new domains.

Comparing the processes through which the anti-hepatitis $\mathrm{C}$ drug sofosbuvir and the artemisinin-combinations against malaria ASAQ have been priced and sold, Maurice Cassier's article provides a powerful analysis of the conflicting value 
regimes at stake. The trajectories of the drugs chosen exemplify two conflicting conjunctions of value, use and global, as well as two regimes of pharmaceutical capitalism.

Sofosbuvir stands at the apex of the hegemonic rent-based global economy of drugs. Its prices - in the range of $\$ 5-80,000$ per treatment bear no relation to its production costs - in the range of \$2-500 per treatment. The discrepancy is a typical outcome of the financial economy of biotech indexed on valuation processes rooted in Nasdaq capitalization, mergers and acquisition of firms, and patent-based exclusive property. Gilead pricing thus sought to maximize profits by pushing the public and private payers' propensity to pay to its limits, using its monopoly to appropriate a significant share of socialized payments, stressing the drug use value in reducing and improving treatments to adjust its own demands at a level slightly below that of the overall existing treatments thus capturing what were previously public and clinical (rather than drug-related) expenditures. This move was not without resistance in the North but mainly faced critique in the South where it radically limited access. Gilead then engaged in a policy of differentiated prices in order to circumvent the threat of patent cancelation and generic production. Its system of voluntary licenses for low-income countries thus created a new geography of production, uses and profits.

In contrast to this economy of rent, the trajectory of ASAQ reveals an alternative industrial and speculative capitalism centered on philanthropic markets in the South and the role of an international consortium dominated by Médecins Sans Frontières and public institutions. The combinations emerged on the basis of low R\&D investments as all molecules had been developed in China or India and were not patented. Firms were involved but kept prices at the level of production costs in order to maximize access either by agreement with the consortium (Sanofi) or because they played the card of a volume-oriented competition (the Chinese generic makers).

Prolonging this reflection on the alternative political economy philanthropic institutions and the generic industry embody, Jean-Paul Gaudilliere's article centers on the epistemic dimensions of the dialectics of bio and capital. Gaudilliere argues that the status of hegemonic pharmaceutical capitalism is not only challenged by the crisis of access but also by a widely discussed crisis of innovation and productivity. Engaging with the abundant literature on this crisis, he uses the historiography of post-WWII pharmacy to propose a critical understanding of the crisis. It argues that the contradictions resulting in mounting issues of access, expertise and novelty are constitutive of the "screening regime" of invention as it emerged in the reorganization of the sector after World War II. These tensions have just accumulated during the last two decades and become more visible. This leads to a new reading of the present turn toward biotechnology and a more speculative (financial) economy of pharmacy.

In his contribution, Laurent Pordié explores a barely visible political economy: that located at the intersection of licit and illicit drug circulation. Following drug smugglers, private suppliers and the circulation of pharmaceuticals-originating in both biomedicine and Ayurveda-between India and Cambodia, he renders the multiple ways in which the mere process of circulation creates and changes value. A nexus of manufacturers, regulators, importers, distributors, middlemen, sellers and 
consumers all share a convergent center of interest in drugs. Each of these actors values pharmaceuticals. Just as their motivations, means and practices of valuing are diverse and sometimes opposed, the resulting pharmaceutical values are multiple, variable and contested.

This gives the dialectic of use and exchange value a peculiar flavor as it places usually rarely discussed material features of the drug center-stage, i.e., whether or not it has been kept in temperature-controlled storage, whether it looks and tastes "normal", whether it is transported or not by bribed officials. Of peculiar interest is in this respect the work done by Cambodia local retailers, usually self-trained pharmacists, who unpack the drugs and assemble them in front of patients in order to craft therapeutic combinations - informal prescriptions-that fit the latter's symptoms and are sold accordingly. In that case locally attributed properties and uses determine the value of a package more than production costs or institutionally negotiated prices. Illegality thus entails a grey political economy of its own as it rearranges the set of anticipations, material commitments and regulatory norms that contribute to drugs' valuation and pricing.

With the trajectory of ayahuasca Emilia Sanabria brings the question one step back along the commodification path. Ayahuasca is a herbal brew that is widespread in Indigenous Upper Amazon. It circulates widely, from Amazonia to Europe, from indigenous communities, to Christian congregations in Latin American cities to the psychiatric treatment centers engaged in the Psychedelic Renaissance. As it is taken up in an ever-growing range of ritual or experimental practices, questions of authority, authenticity, propriety or safety have become acute. This case allows us to interrogate contemporary processes of value making as radically different and highly stratified forms of valorization encounter each other. For the time being, ayahuasca has no clearly determined capitalist value, yet such value is emergent, speculative, promissory and contested. Its value thus lies primarily in its potential to address intractable mental health problems such as addiction or depression, a future horizon of value still being constructed and consolidated in relation to potential markets. Ayahuasca is therefore less a drug and a commodity than it is an intractable and highly valorized mangle between the local brew, the participant's individual subjectivity and the collective life of ayahuasqueros.

Does this imply that ayahuasca must be considered as a drug outside the world of drugs, a non-thing exemplifying the radical limits of capitalistic and biopolitical valorization? Sanabria's response is a clear no. Ayahuasca is a boundary object, a promise of value whose future rests on an emerging epistemic reformulation. Its scientific and medical supporters envisage the emergence of an alternative to mental health's biomedical failures. The circuits of ayahuasca's valorization reveal a complex coproduction of value that makes strategic use of heterogeneous scales, sites and situations giving the promissory horizon of extra-pharmacological value a key role.

Echoing Pordié's local retailers and their symptomatic logic of prescription as well as Cassier's centrality of access in the philanthropic logic of copying, Andrew McDowell's article explores the bottom end of the valorization chain: GP's practices. Based on fieldwork among practitioners in Mumbai's slums, his contribution does not interrogate the value of a drug but the value of a practice. Often indicted 
as profit-seeking bad practitioners contributing to the rise of antibiotic-resistant TB infections as a consequence of out-of-norm prescription patterns, McDowell's private practitioners reveal another dialectic of market and health. This accepted discourse does not take into account the multiple uncertainties, ethical complexity, and personal relationships involved in providing care in exchange for money in a setting of scarce personal and public resources.

Closely following the uses of pharmaceuticals and the relations between the conduct of clinical examination and prescriptions, McDowell shows how the logic economists and critics alike place on the impact of financial incentives (monetary contributions received from drug companies, testing services or fellow specialists) is circumvented by the practice of "managing health and marketing service." Operating in what is paradoxically a competitive and dense medical environment, Mumbai slums' doctors manage the effects of a pharmaceutical value chain that produces profit by fulfilling patient's health needs and desires. Using pharmaceuticals in order to treat symptoms and consolidate their clientele while taking into account the constant flux of patients between forms of care, they create valuable but segmented conjunctions between modes of care and most valued drugs.

The essays gathered in this collection originate in a workshop organized in Paris in June 2016 (The Making of Pharmaceutical Value: Drugs, Diseases and the Political Economies of Global Health) within the framework of the European Research Council GLOBHEALTH project (340510)_From international to global: Knowledge, disease and the postwar government of health.

\section{References}

Abraham, John. 2010. Pharmaceuticalization of Society in Context: Theoretical, Empirical and Health Dimensions. Sociology 44 (4): 603-622.

Adams, Vincanne, ed. 2016. Metrics: What Count in Global Health. Durham: Duke University Press.

Aglietta, Michel. 1979. A Theory of Capitalistic Regulation. The US Experience. London: Verso.

Bächi, Beat. 2009. Vitamin C für Alle! Pharmazeutische Produktion, Vermarktung und Gesundheitspolitik (1933-1953). Zürich: Chronos Verlag.

Bell, Susan, and Anne Figurt. 2012. Medicalization and Pharmaceuticalization at the Intersections: Looking Backwards, Sideways and Forwards. Social Science and Medicine 75 (5): 775-783.

Biehl, Joao. 2007. Pharmaceuticalization: Aids Treatment and Global Health Politics. Anthropological Quarterly 80 (4): 1083-1126.

Biehl, Joao. 2009. Will to Live : Aids Therapies and the Politics of Survival. Princeton: Princeton University Press.

Boyer, Robert. 2015. Economie politique des capitalismes. Théorie de la régulation et des crises. Paris: La Découverte.

Castel, Robert. 2002 (English translation). From Manual Workers to Wage Laborers. Transformation of the Social Question. London: Routledge.

Chatterjee, Partha. 1993. The Nation and its Fragments. Princeton: Princeton University Press.

Chorev, Nitsan. 2012. The World Health Organization between North and South. Ithaca: Cornell University Press.

Clarke, Adele E., L. Mamo, J.R. Fosket, J.R. Fishman, and J. Shim, eds. 2010. Biomedicalization: Technoscience, Health and Illness in the U.S. Durham, NC: Duke University Press.

Coderey, Céline, and Laurent Pordié, eds. 2016. Circulation and Governance of Asian Medicine. New York: Routledge.

Cooper, Melinda, and Catherine Waldby. 2014. Clinical Labor : Tissue Donors and Research Subjects in the Global Economy. Durham: Duke University Press. 
Dumit, J. 2012. Drugs for Life: How Pharmaceutical Companies Define Our Health. Durham, NC: Duke University Press.

Esping-Andersen, Gosta. 1990. The Three Worlds of Welfare Capitalism. Cambridge: Polity Press.

Foucault, Michel. 2004a. Naissance de la biopolitique. Paris: EHESS, Gallimard, Seuil.

Foucault, Michel. 2004b. Sécurité, territoire, population. Paris: EHESS, Gallimard, Seuil.

Gaudillière, Jean-Paul. 2014. De la santé publique internationale à la santé globale. L'OMS, la Banque Mondiale et le gouvernement des thérapies chimiques. In Le gouvernement des technosciences, ed. D. Pestre. Paris: La Découverte.

Gaudilliere, Jean-Paul, Claire Beaudevin, Christoph Gradmann, Anne Lovell, and Laurent Pordié, eds. 2020. Global Health and the New World Order: Historical and Anthropological Approaches to a Changing Regime of Governance. Manchester: Manchester University Press.

Gaudillière, Jean-Paul, and Volker Hess, eds. 2013. Ways of Regulating Drugs in the 19th and 20th Centuries. Basingstoke and New York: Palgrave Macmillan.

Gaudilliere, Jean-Paul, Andrew McDowell, Claudia Lang, and Claire Beaudevin, eds. 2021. Global Health for All: Knowledge, Politics, Practices. New Brunswick: Rutgers University Press.

Gaudillière, Jean-Paul, and Ulrike Thoms, eds. 2015. The Development of Scientific Marketing in the Twentieth Century. New York: Pickering \& Chatto.

Greene, Jeremy A. 2007. Prescribing by Numbers: Drugs and the Definition of Disease. Baltimore: The Johns Hopkins University Press.

Greene, Jeremy A. 2014. Generic. The Unbranding of Modern Medicine. Baltimore: Johns Hopkins University Press.

Haller, Lea. 2012. Cortison: Wissensgeschichte eines Hormons, 1900-1955. Zürich: Chronos Verlag.

Hayden, Cori. 2007. A Generic Solution? Pharmaceuticals and the Politics of the Similar in Mexico. Current Anthropology 48 (4): 475-495.

Kaufman, Sharon R. 2015. Ordinary Medicine: Extraordinary Treatments, Longer Lives, and Where to Draw the Line. Durham: Duke University Press.

Livingston, Julie. 2012. Improvizing Medicine: An African Oncology Ward in an Emerging Cancer Epidemic. Durham NC: Duke University Press.

Marx, Karl. 1993 (1857). Grundrisse: Foundations of a Critique of Political Economy. London: Penguin Books.

Marx, Karl. 1976 (1867). Capital: A Critique of Political Economy. London: Penguin Books.

Murphy, Michelle. 2017. The Economization of Life. Durham: Duke University Press.

Ong, Aihwa, and Stephen J. Collier. 2005. Global Assemblages: Technology, Policy and Ethics as Anthropological Problems. Malden: Blackwell.

Peterson, Kristin. 2014. Speculative Markets: Drug Circuits and Derivative Life in Nigeria. Durham: Duke University Press.

Petryna, Adriana. 2009. When Experiments Travel: Clinical Trials and the Global Search for Human Subjects. Princeton, NJ: Princeton University Press.

Petryna, Adriana, and Arthur Kleinman. 2006. The Pharmaceutical Nexus. In Global Pharmaceuticals: Ethics, Markets, Practices, ed. A. Petryna, A. Lakoff, and A. Kleinman, 1-32. Durham, NC: Duke University Press.

Sunder Rajan, Kaushik. 2017. Pharmocracy: Value, Politics and Knowledge in Global Medicine. Durham: Duke University Press.

World Bank. 1993. Investing in Health. World Development Report 1993. Washington DC: World Bank Group.

Publisher's Note Springer Nature remains neutral with regard to jurisdictional claims in published maps and institutional affiliations.

Jean-Paul Gaudilliere is a senior researcher at the Institut National de la Santé et de la Recherche Médicale and director of the Center for Science, Medicine, Health and Society (CERMES3) in Paris. His research in the history of the life sciences and medicine during the twentieth century. He is the author of Inventer la biomédecine. La France, l'Amérique et la production des savoirs du vivant (1945-1965) (La Découverte, 2002). His recent work focuses on the history of pharmaceutical innovation and the uses of drugs on the one hand, the dynamics of health globalization after World War II on the other hand. He is co-author of Global Health for all: Knowledge, Practices, Politics (Rutgers, in press). 
Kaushik Sunder Rajan is Professor of Anthropology and Co-Director, Chicago Center for Contemporary Theory at the University of Chicago. He works on the global political economy of the life sciences and biomedicine, with an empirical focus on India, South Africa and the United States. He is the author of Biocapital: The Constitution of Postgenomic Life (2006), Pharmocracy: Value, Politics and Knowledge in Global Biomedicine (2017), and Multisituated: Ethnography as Diasporic Praxis (2021). He is currently embarked on a research project that studies the intersections between health, law and constitutionalism in South Africa. 